\title{
Identification of a Novel V1-type AVP Receptor Based on the Molecular Recognition Theory
}

\author{
Victoria L. M. Herrera and Nelson Ruiz-Opazo \\ Section of Molecular Genetics, Whitaker Cardiovascular Institute, Boston University School of Medicine, \\ Boston, Massachusetts, USA \\ Accepted April 15, 2001
}

\begin{abstract}
Background: The molecular recognition theory predicts that binding domains of peptide hormones and their corresponding receptor binding domains evolved from complementary strands of genomic DNA, and that a process of selective evolutionary mutational events within these primordial domains gave rise to the high affinity and high specificity of peptide hormone-receptor interactions observed today in different peptide hormone-receptor systems. Moreover, this theory has been broadened as a general hypothesis that could explain the evolution of intermolecular protein-protein and intramolecular peptide interactions. Materials and Methods: Applying a molecular cloning strategy based on the molecular recognition theory, we screened a rat kidney cDNA library with a vasopressin (AVP) antisense oligonucleotide probe, expecting to isolate potential AVP receptors.
\end{abstract}

Results: We isolated a rat kidney cDNA encoding a functional Vl-type vasopressin receptor. Structural analysis identified a 135 amino acid-long polypeptide with a single transmembrane domain, quite distinct from the rhodopsin-based $G$ protein-coupled receptor superfamily. Functional analysis of the expressed V1-type receptor in Cos-1 cells revealed AVP-specific binding, AVP-specific coupling to $\mathrm{Ca}^{2+}$ mobilizing transduction system, and characteristic V1-type antagonist inhibition.

Conclusions: This is the second AVP receptor cDNA isolated using AVP antipeptide-based oligonucleotide screening, thus providing compelling evidence in support of the molecular recognition theory as the basis of the evolution of this peptide hormone-receptor system, as well as adds molecular complexity and diversity to AVP receptor systems.

\section{Introduction}

Arginine-vasopressin (AVP) is a nonapeptide hormone with a diverse spectrum of biological effects in almost every organ system. Briefly, it is involved in salt and water balance in the kidney (1); increased glycogenolysis and gluconeogenesis in the liver (1); chronotrophy and inotropy of the heart (1); increased fluid secretion in the ciliary body and blood-brain barrier (1); modulation of specific neuronal activation and animal behavior, particularly memory retention, in the central nervous system (1); paracrine regulation of gonadal functions (1); and regulation of blood pressure (2-4).

With such markedly diverse biological responses, it is not surprising that receptor isoform diversity constitutes a mechanism for said functional diversity. AVP receptors have been classified as VI-type AVP receptors, which are functionally coupled to $\mathrm{Ca}^{2+}$ mobilization through enhanced inositol lipid breakdown $(5,6)$, and V2-type vasopressin receptors, which are functionally coupled to adenylate cyclase $(1,5)$ and have a ligand specificity identical to that of vasopressin receptors involved in the

Address correspondence and reprint requests to: Nelson Ruiz-Opazo, PhD, Whitaker Cardiovascular Institute, W609, 700 Albany Street, Boston, Massachusetts 02118. Phone: 617-638-4384; Fax: 617-638-4066; e-mail: nruizo@bu.edu antidiuretic response to vasopressin. Several groups have recently cloned V1-type $(7,8)$ and V2-type $(9,10)$ vasopressin receptors using standard expression cloning-and hybridization/polymerase chain reaction (PCR)-based strategies. We recently identified two novel receptors, the AngII/AVP receptor (11) and the ET-1/AngII receptor (12), utilizing the molecular recognition theory (MRT) as our strategic molecular framework.

The MRT postulates that complementary nucleotide sequences can specify peptides that could interact through complementary structures as a result of their inverted pattern of amino acid hydropathy (13). This prediction is based on the fundamental observation that the hydropatic character of an amino acid appears to be determined by the second base of a particular codon (13). Thus, a second base $\mathrm{U}$ will generally specify hydrophobic amino acids, in contrast to a second base A, which will specify hydrophilic amino acids (13). The MRT further implies that peptide hormones and corresponding receptors evolved from complementary strands of genomic DNAs. We present herein the isolation, characterization, and functional expression of a cDNA encoding a novel Vl-type AVP receptor. It is the second AVP receptor isoform cloned using a cDNA screening strategy based on MRT, and thus provides insight into the evolutionary origin of the AVP ligand-receptor system. 


\section{Materials and Methods}

\section{cDNA Screening and Nucleotide Sequencing}

An oligonucleotide was synthesized (Research Genetics, Huntsville, AL, USA) based on the cRNA sequence of the rat AVP mRNA (14) corresponding to the AVP antipeptide as follows: TCC-TCT-TGGGCA-GTT-CTG-GAA-GTA-GC. A $\lambda$ gtll rat kidney cDNA library $\left(10^{6} \mathrm{PFU}\right)$ was hybridized with $10^{6}$ cpm $\mathrm{ml}^{-1}{ }^{32} \mathrm{P}$-end labeled oligonucleotide probe at $37^{\circ} \mathrm{C}$ overnight in the following buffer: $6 \mathrm{X}$ SSPE (1 $\mathrm{M} \mathrm{NaCl}, 60 \mathrm{mM} \mathrm{NaH} \mathrm{PO}_{4}$ [pH 7.4], $6 \mathrm{mM}$ EDTA [pH 7.4]), $100 \mu \mathrm{g} \mathrm{ml}^{-1}$ of denatured calf thymus DNA, $0.1 \%$ sodium pyrophosphate, $1 \%$ SDS (sodium dodecyl sulfate), and $100 \mu \mathrm{g} \mathrm{ml}^{-1}$ of polyadenylic acid. Washes were done in $2 \mathrm{X}$ SSPE (sodium chloride, sodium phosphate EDTA) or $\left(0.36 \mathrm{M} \mathrm{NaCl}, 20 \mathrm{mM} \mathrm{Na} \mathrm{HPO}_{4}, 2 \mathrm{mM}\right.$ EDTA [pH 7.4]) $0.1 \%$ pyrophosphate, and $0.1 \%$ SDS at $40^{\circ} \mathrm{C}$ for three 15-min intervals. Nine clones were isolated and plaque purified. Among these clones, the V6 cDNA $(\sim 1.7 \mathrm{~kb})$ was subcloned into pSP73 plasmid vector and subsequently sequenced on both strands as described $(11,12)$. The cDNA nucleotide sequence data for the novel V1 type AVP receptor presented in this paper will appear in the GenBank database under the accession number AF336872.

\section{Northern Blot Analysis}

Northern blot analysis was performed essentially as described (15). Total RNA was isolated from different tissues from Sprague-Dawley rats. Total RNA (5 $\mu \mathrm{g}$ per lane) was size separated on a $1 \%$ agarose formaldehyde gel, transferred to nitrocellulose, and hybridized to the ${ }^{32} \mathrm{P}$-labelled 1.7-kb V6 cDNA. The blot was washed and exposed for $24 \mathrm{hr}$ at $-80^{\circ} \mathrm{C}$ with intensifying screens.

\section{Transfection and Isolation of Transfected Cos 1 Cells}

Cos- 1 cells (green monkey kidney cells, ATCC) were grown in Dulbecco's modified Eagle's medium supplemented with $10 \%$ fetal calf serum and antibiotics (Gibco, Rockville, MD, USA). For expression studies, the 1.7-kb V6 cDNA previously subcloned in the EcoRI site of pSP73 transcription vector (Promega, Madison, WI, USA) was excised using SmaI and EcoRV restriction enzymes. The SmaI/EcoRV 1.7-kb V6 cDNA insert was then subcloned in both orientations into the blunt-ended NheI site of the pMAMneo expression vector (Clontech, Palo Alto, CA, USA). The two V6-pMAMneo recombinants, $(+)$ and $(-)$, were then transfected into Cos- 1 cells via the calcium phosphate precipitate method (16). A mixed population of stable neomycin-resistant transfectants, CoslpMAM-V6 $(+)$ and $(-)$ cells, were selected with $500 \mu \mathrm{g} \mathrm{ml}^{-1}$ G418 antibiotic (effective concentration $=250 \mu \mathrm{g} \mathrm{ml}^{-1}$ as per manufacturer's specifications [Gibco]) and maintained in G418 for expression studies. pMAMneo transfected Cos-1 cells were developed in parallel as controls.

\section{Binding Assays}

Binding experiments were done as described (17) with the following specifications. Each assay point consisted of $10^{6}$ cells cultured in P-35 dishes; binding assays were done in $1 \mathrm{ml}$ of binding buffer (17) containing $10^{-10}$ to $5 \times 10^{-6} \mathrm{M}$ concentration of ligands; cells with bound ${ }^{3} \mathrm{H}$-AVP were collected with $1 \mathrm{ml}$ of $10 \mathrm{mM}$ Tris $\mathrm{HCl} \mathrm{pH} 7.4,10 \mathrm{mM}$ EDTA, $3 \%$ Triton X-100, and subsequently counted in a scintillation counter. All incubations were performed at $30^{\circ} \mathrm{C}$ for $30 \mathrm{~min}$. Specific binding was determined as the difference between the total radioactivity bound to cells at the different ligand concentrations utilized and the radioactivity bound to control cells containing $10 \mu \mathrm{M}$ of AVP. The specific activity of the ${ }^{3} \mathrm{H}$-AVP (NEN) was $66 \mathrm{Ci} \mathrm{mmol}^{-1}$. No specific binding of ${ }^{3} \mathrm{H}$-AVP was detected in control nontransfected and pMAMneo-transfected Cos-1 cells. Competition curves of ${ }^{3} \mathrm{H}$-AVP binding using intact CosIpMAMV6 cells were performed with $5 \mathrm{nM}{ }^{3} \mathrm{H}$-AVP in the presence of increasing concentrations $\left(10^{-10}\right.$ to $5 \times$ $10^{-6} \mathrm{M}$ ) of the different competitors tested.

\section{$\mathrm{Ca}^{+}$Mobilization Assays}

${ }^{45} \mathrm{Ca}^{2+}$ efflux assays were done essentially as described (18). Cell cultures (P-35 dishes) were equilibrated with ${ }^{45} \mathrm{Ca}^{2+}$ under standard growth conditions (DMEM $+10 \%$ FCS $+500 \mu \mathrm{g} \mathrm{ml}^{-1} \mathrm{G} 418+$ $5 \mu \mathrm{Ci} \mathrm{ml}{ }^{-1}$ of ${ }^{45} \mathrm{CaCl}_{2}$ ) for $18-20 \mathrm{hr}$. Assays were then initiated by removal of the ${ }^{45} \mathrm{Ca}^{2+}$ media and rapid sequential washings and aspirations with three $1 \mathrm{ml}$ aliquots of physiologic buffer (PB; composition in millimolar concentrations: $\mathrm{NaCl} 140$; $\mathrm{KCl}$ 5.4; $\mathrm{CaCl}_{2}$ 1.8; $\mathrm{MgCl}_{2}$ 1.6; D-glucose 5.5; Hepes 5, pH 7.4). One milliliter of assay solution containing appropriate ligands dissolved in PB was promptly added and efflux was allowed to proceed for the specific time intervals. Efflux was terminated by rapid washing and aspiration with three $1-\mathrm{ml}$ aliquots of $\mathrm{MgCl}_{2}$-free $\mathrm{PB}$ containing $5 \mathrm{mM} \mathrm{LaCl}_{3}$. Residual ${ }^{45} \mathrm{Ca}^{2+}$ content was expressed relative to total isotope present in cultures that received the wash protocol without any intervening efflux interval (time zero averaged $9000 \pm 857 \mathrm{cpm}$ per P-35 dish). All assays were done at $37^{\circ} \mathrm{C}$.

\section{Inositol Phosphate Accumulation}

Inositol phosphate measurements were done as follows. Cells (confluent P-35 dishes) were incubated in a buffer containing $130 \mathrm{mM} \mathrm{NaCl}, 5 \mathrm{mM} \mathrm{KCl}$, $1 \mathrm{mM} \mathrm{MgCl}, 1 \mathrm{mM} \mathrm{CaCl} 2,10 \mathrm{mM}$ glucose, and $20 \mathrm{mM}$ Hepes, pH 7.4, with or without hormone. After exposure to hormone or buffer $(1 \mathrm{ml}$ per dish, $37^{\circ} \mathrm{C}$ for $10-30 \mathrm{sec}$ ), the reaction was terminated by rapid aspiration of incubation buffer and subsequent addition of $1 \mathrm{ml}$ of ice-cold $10 \%$ trichloroacetic acid. Cells were then scraped with a rubber policeman and the entire content of the dish was transferred to a test tube. After centrifugation $(10,000 \mathrm{~g} \times 10 \mathrm{~min})$, 
the protein precipitate was discarded and the supernatant was extracted three times with equal volumes of diethyl ether. The upper ether phase was discarded and samples were adjusted to $\mathrm{pH} 7$ with $50 \mathrm{mM}$ Tris base. Inositol-1,4,5-trisphosphate (IP3) content was determined by a sensitive IP3 $\left[{ }^{3} \mathrm{H}\right]$ binding protein assay system as per manufacturer's specifications (D-myo-Inositol 1,4,5-trisphosphate [IP3] $\left[{ }^{3} \mathrm{H}\right]$ assay system, code TRK 1000, Amersham, Piscataway, NJ, USA).

\section{Immunocytochemistry}

A polyclonal rabbit antipeptide antibody (custommade by Multiple Peptide Systems, San Diego, CA, USA) was raised against the synthetic peptide $\mathrm{L}_{11} \mathrm{WLPEDGQVR}_{20}$ spanning a portion of the predicted extracellular domain of the V6-encoded vasopressin receptor (Fig. 2). Control CoslpMAMneo and test Cos1pMAM-V6 cells were reacted with this antibody (1:500) and immunostained as described previously $(11,12)$. Cells were blocked in phosphatebuffered saline (PBS) plus $1 \%$ bovine serum albumin (BSA) for $30 \mathrm{~min}$ at $4^{\circ} \mathrm{C}$. Cells were reacted with primary antibody in PBS plus $1 \%$ BSA for $14 \mathrm{hr}$ at $4^{\circ} \mathrm{C}$. After two washes with PBS at $4^{\circ} \mathrm{C}$, cells were fixed with Bouin's solution (Sigma, St. Louis, MO, USA) for $15 \mathrm{sec}$ at room temperature. After extensive washing with PBS, cells were sequentially reacted with biotinylated goat anti-rabbit IgG (BioRad, Hercules, CA, USA), followed by streptavidin $10 \mathrm{nM}$ colloidal gold labeled and finally subjected to silver enhancement. No immunostaining was observed on Cos IpMAM-V6 cells when the antipeptide antibody was coincubated with the antigenic peptide $(1 \mathrm{mM})$ or replaced by preimmune serum at a 1:500 dilution.

\section{Results}

\section{Isolation and Tissue Distribution of V6 CDNA}

The molecular recognition theory states that peptide ligands and their receptor binding sites could have evolved from complementary nucleotide sequences (19). We took this notion one step further and applied it to the screening of putative AVP receptor cDNA clones. Using the rat AVP antipeptide-based oligonucleotide as the hybridization probe, we isolated nine cDNA clones from a rat kidney cDNA library. Three of the clones were identified and encoded the dual AngII/AVP receptor that we recently characterized (11). The next largest cDNA clone, V6 $(1.7 \mathrm{~kb})$, was then analyzed. This cDNA did not crosshybridize with the previously characterized cDNA encoding the AngII/AVP receptor (data not shown). Northern blot analysis at stringent hybridization conditions revealed two mRNAs: $3.0 \mathrm{~kb}$ and $3.5 \mathrm{~kb}$ (Fig. 1). The mRNAs were detected in all tissues tested with the following relative abundance: rat aortic smooth muscle cells (A-10 cells, ATCC) $>$ adrenal gland (Adr.Gl.) > pulmonary vas-

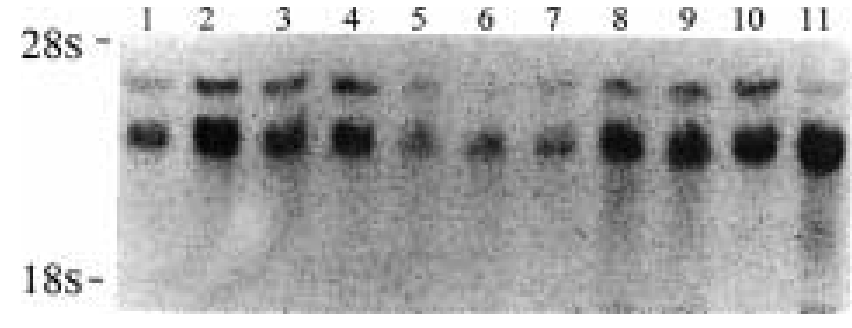

Fig. 1. V6 mRNA size and tissue distribution. RNA blot analysis of different adult rat tissue total cellular RNAs detect two sizes of V6 mRNAs: $3.5 \mathrm{~kb}$ and $3.0 \mathrm{~kb}$ (most abundant). Using equal amounts $(5 \mu \mathrm{g})$ of RNAs per tissue and the $1.7-\mathrm{kb}$ V6 cDNA as hybridization probe as described (15), the relative abundance of the V6 mRNA are noted: rat aortic smooth muscle cells (A-10 cells, ATCC, lane 11) > adrenal gland (lane 2) > pulmonary vascular tissue (lane 8 ) = rat aortic tissue (lane 9 with endothelium, lane 10 without endothelium) $>$ brain (lane 3) $=$ heart (lane 4) $>$ kidney (lane 1$)>$ skeletal muscle (lane 5) = lung (lane 7) = liver (lane 6). The relative location of the $28 \mathrm{~S}$ and $18 \mathrm{~S}$ ribosomal RNAs are indicated.

cular tissue (Lung Vasc.) $=$ rat aortic tissue $\left(\mathrm{A}_{\mathrm{o}}\right)>$ brain $=$ heart $>$ kidney $>$ skeletal muscle (Sk.m.) $=$ lung $=$ liver. Because of the relative abundance in blood vessels and in A-10 aortic smooth muscle cells (cell line in which V1-type vasopressin receptors have been detected) (20), we hypothesized that the V6 cDNA might encode a V1-type AVP receptor.

\section{Structural Analysis of the V6 cDNA}

The nucleotide sequence (Fig. 2) of the 1.7-kb V6 cDNA revealed an open reading frame (ORF) containing a typical initiating methionine with 9 of 13 identical nucleotides with the Kozak consensus sequence (21). The deduced resultant polypeptide is 135 amino acids long.

Comparison with the nucleotide sequence of the AVP antipeptide-based oligonucleotide probe revealed only one region with the highest degree of nucleotide identity, 19 nucleotides over a stretch of 22 nucleotides (86\%) (Fig. 2A). This marks the putative AVP binding site based on the MRT. We note the antisense peptide from frame 2 (Fig. 2C) as the putative evolutionary AVP precursor binding domain. Analysis of the hydropathy profile of the V6 cDNA encoded polypeptide based on the Kyte-Doolittle scale using an amino acid window of 17 for analysis $(22,23)$ reveals a single putative transmembrane domain (Fig. 2A). The identification of a putative AVP binding domain and a single putative transmembrane region places the $\mathrm{N}$-terminus extracellularly, and the $\mathrm{C}$-terminus intracellularly. The $\mathrm{C}$-terminal intracellular domain has one potential protein kinase C (PKC)-phosphorylation site whose function remains to be determined.

\section{Functional and Pharmacologic Characterization} of the V6 cDNA Encoded AVP Receptor

The V6 cDNA clone was subcloned into the pMAMneo expression vector in two orientations and trans- 
A

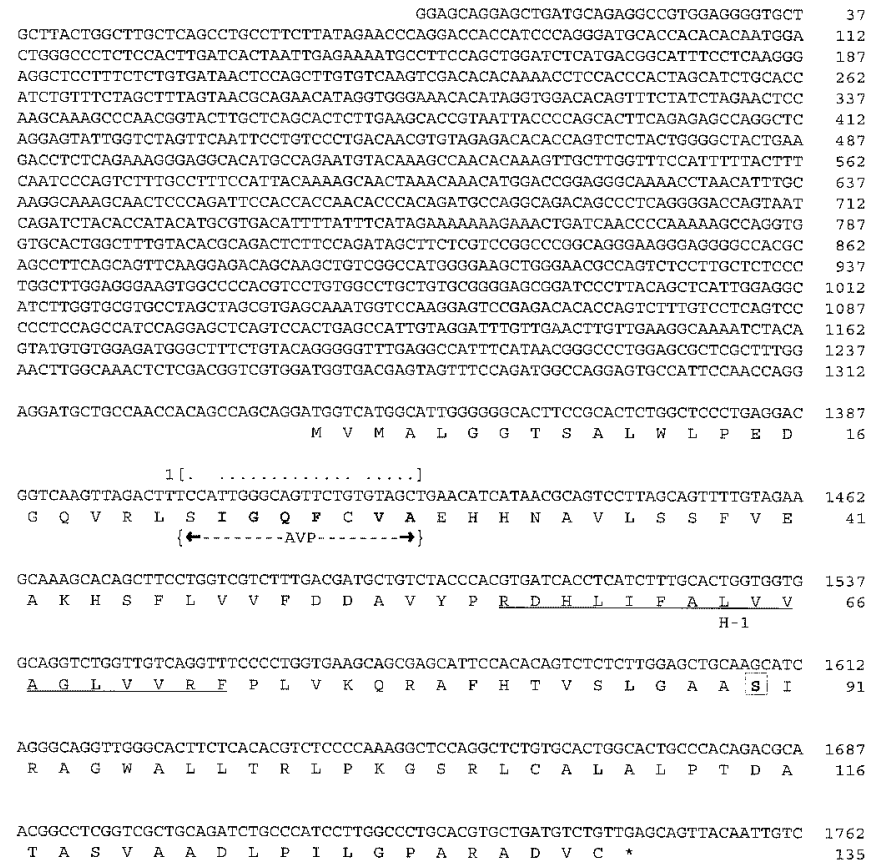

C

\begin{tabular}{|c|c|c|c|c|c|c|c|c|c|}
\hline $5^{\prime}-\mathrm{TCC}$ & TCT & TGG & GCA & GTT & $\mathrm{CTG}$ & GAA & GTA & $G C A-3 \prime$ & AVP CRNA \\
\hline $\mathrm{s}$ & $s$ & W & A & $\mathrm{v}$ & $\mathrm{L}$ & $\mathrm{E}$ & $\mathrm{V}$ & A. & AVP AP Frame \\
\hline $\mathrm{P}$ & I & $\mathrm{G}$ & $Q$ & $\mathrm{~F}$ & W: & K & * & & AVP AP Frame \\
\hline
\end{tabular}

$* * * * * * * * * * * * * \quad * * * * *$

5'-CCT CTT GGG CAG TTC TGGAA GTA GCA-3'

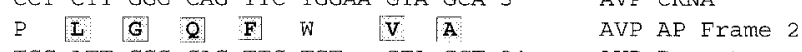
5'-TCC ATT GGG CAG TTC TGT-- GTA GCT-3' AVP Receptor
B

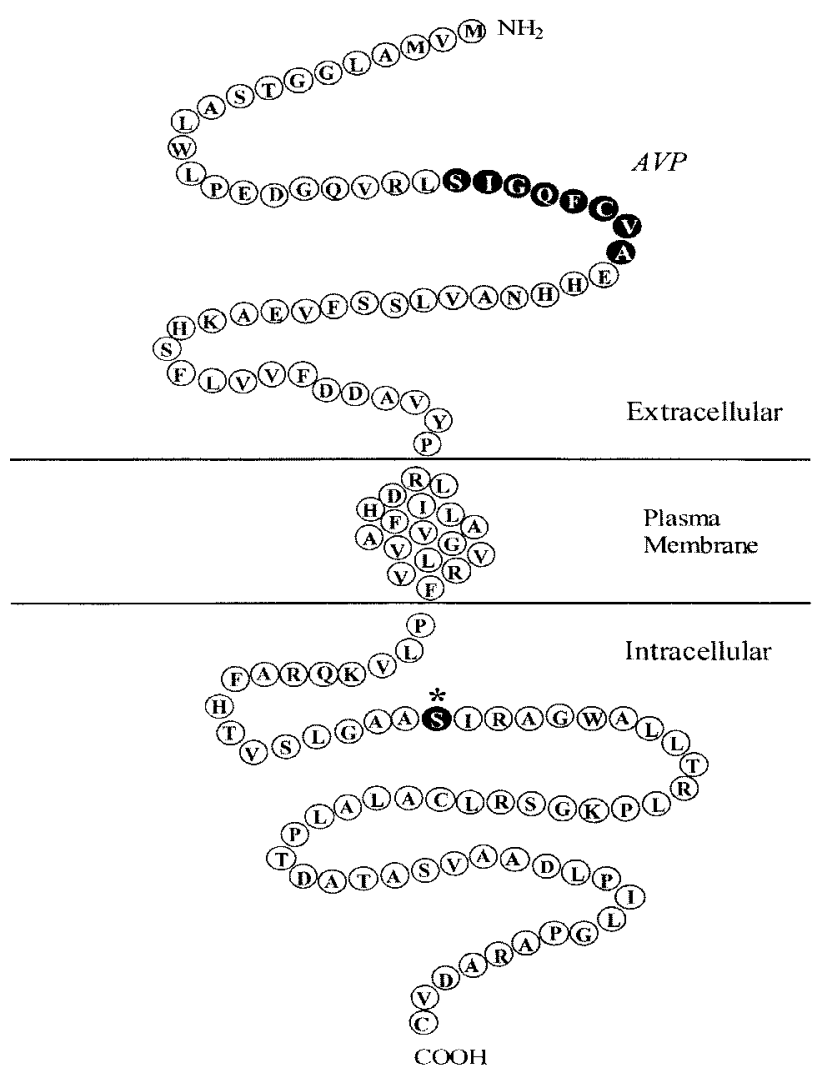

Fig. 2. Sequences and structural features of the V6 cDNA encoded AVP V1-type receptor. (A) The nucleotide sequence of the 1.7-Kb V6 cDNA is presented with the deduced amino acid sequence (in single letter amino acid code). The ORF contains the initiating methionine that is identified by $9 / 13$ identity with the Kozak consensus sequence (21). A single putative transmembrane domain (H-1) is predicted based on the Kyte-Doolittle scale with a window of 17 amino acids $(22,23)$. The single region of highest identity with the AVP cRNA-based oligonucleotide probe is marked [ ], showing $86 \%$ identity over a stretch of 22 nucleotides; identical nucleotides are dotted. The serine residue within the consensus sequence for a potential PKC phosphorylation site is highlighted. (B) Proposed structure of the V6 cDNA encoded AVP V1-type receptor. Based on the localization of a single 17 amino acid-long hydrophobic region $(\mathrm{H}-\mathrm{l})$ as putative transmembrane domain and the putative AVP binding domain (AVP) proximal to $\mathrm{H}-1$, the putative structure is oriented with the $\mathrm{N}$-terminus extracellularly and the C-terminus intracellularly. Black circles highlight the putative AVP binding domain and the potential PKC-phosphorylation site. (C) Comparison of the AVP cRNA sequence with the nucleotide and amino acid sequence of the V6 encoded AVP receptor identifies $a_{22-29}$ as potential AVP binding domain. The stippled areas indicate regions of homology. Nucleotides encompassing the AVP binding domain that are present in identical codon position within the AVP antisense peptide frame 2 are indicated by asterisks.

fected into Cos- 1 cells followed by G418 antibiotic selection. pMAMneo G418-resistant cells were developed in parallel and served as controls. Based on the hypothesis that the V6 cDNA might encode a V1-type AVP receptor, we investigated AVP-induced V6 cDNA-receptor coupling to $\mathrm{Ca}^{2+}$ mobilization. As predicted, only one orientation, pMAM-V6 (+), expressed a functional AVP-responsive cell membrane receptor (as measured by ${ }^{45} \mathrm{Ca}^{2+}$ efflux assays) when transfected into Cos-1 cells, Cos IpMAM-V6 cells. pMAMneo cells did not exhibit AVP-specific binding or AVP-induced $\mathrm{Ca}^{2+}$ mobilization. All subsequent analyses were done with CosIpMAMV6 cells.

As shown in Figure 3A, 0.1 $\mu \mathrm{M}$ AVP induced ${ }^{45} \mathrm{Ca}^{2+}$ efflux in Cos 1pMAM-V6 cells as measured by percent ${ }^{45} \mathrm{Ca}^{2+}$ retained. The response was also quite rapid, reaching plateau levels $\left(40-45 \%{ }^{45} \mathrm{Ca}^{2+}\right.$ retained) at $10 \mathrm{sec}$. Control incubation buffer, without AVP, did not elicit ${ }^{45} \mathrm{Ca}^{2+}$ efflux. Because of the precedent dual peptide hormone/single receptor systems, AngII/AVP receptor (11) and ET-1/AngII receptor (12), we analyzed the hormone response profile of $\mathrm{Ca}^{2+}$ mobilization in CoslpMAM-V6 

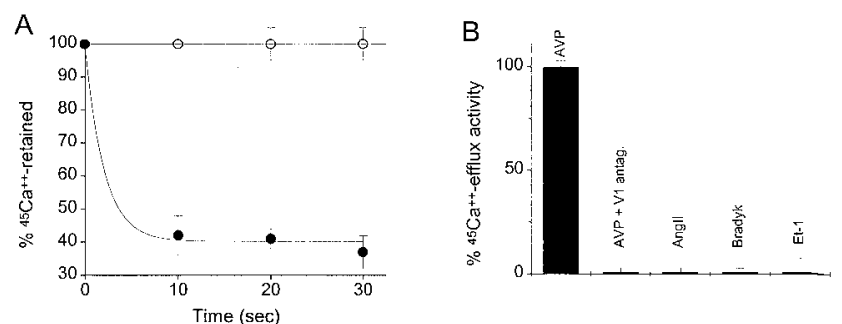

C
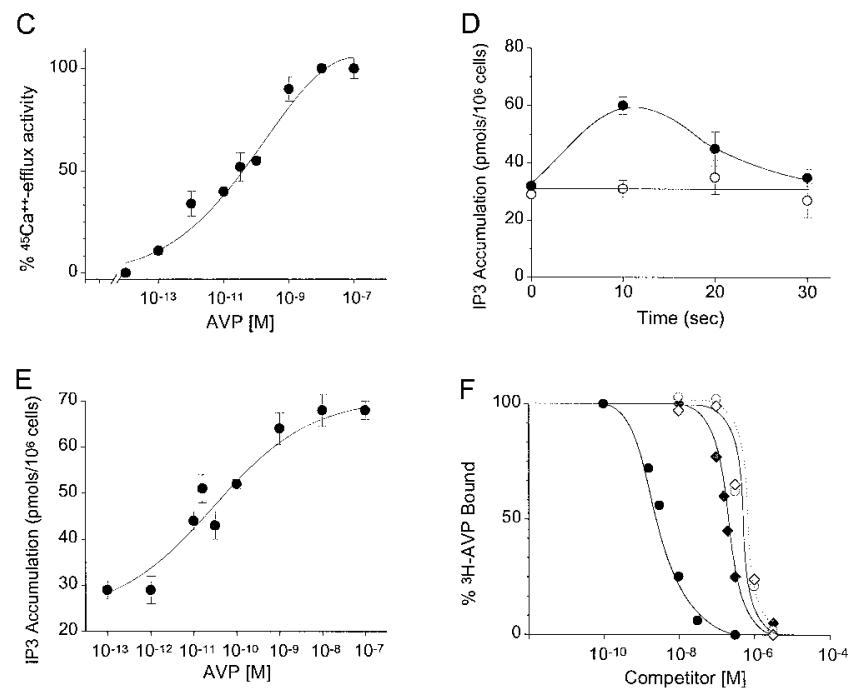

Fig. 3. Functional characterization of the V6 cDNA encoded AVP receptor expressed in CoslpMAM-V6 cells. (A) AVPinduced ${ }^{45} \mathrm{Ca}^{2+}$ mobilization in intact CoslpMAM-V6 cells. Cells were exposed to $0.1 \mu \mathrm{M}$ AVP $(\bullet)$ in comparison to basal control conditions (i.e., no hormone added [०]) and ${ }^{45} \mathrm{Ca}^{2+}$-efflux measured as the \% ${ }^{45} \mathrm{Ca}^{2+}$-retained at 10, 20 and 30 sec. (B) Peptide hormone response profile of ${ }^{45} \mathrm{Ca}^{2+}$ mobilization in Cos lpMAMV6 cells. The $\%{ }^{45} \mathrm{Ca}^{2+}$ efflux activity was determined in response to various peptide ligands (1 nM): AVP, angiotensin II (AngII), bradykinin (bradyk), and endothelin-1 (Et-1). Specificity for AVP stimulation was tested with the concurrent incubation of AVP (1 nM) with a Vl antagonist, $\left[\mathrm{dCH}_{2}\right)_{5}$, Tyr(Me)]-AVP (24) (V1 antag) at $100 \mathrm{nM} .{ }^{45} \mathrm{Ca}^{2+}$ efflux activity was defined as the difference between cells exposed to PB containing the different ligands and cells exposed to PB alone; incubation time was 10 sec. Results are expressed as percent of ${ }^{45} \mathrm{Ca}^{2+}$ efflux activity relative to the activity obtained in Cos IpMAM-V6 cultures exposed to $1 \mathrm{nM}$ AVP. (C) Concentration dependence of AVPinduced $\mathrm{Ca}^{2+}$ mobilization in Cos lpMAM-V6 cells. ${ }^{45} \mathrm{Ca}^{2+}$ efflux was measured in response to varying concentrations of AVP (from $\left.10^{-13}-10^{-7} \mathrm{M}\right)$ at the 10 -sec time point. Results are expressed as percent ${ }^{45} \mathrm{Ca}^{2+}$ efflux activity relative to Cos lpMAM-V6 cells exposed to $100 \mathrm{nM}$ AVP for $10 \mathrm{sec}$ (D) Characterization of AVPinduced IP3 formation in Cos IpMAM-V6 cells. IP3 formation (pmols $10^{-6}$ cells) was measured in Cos 1 pMAM-V6 cells exposed to $0.1 \mu \mathrm{M}$ AVP $(\bullet)$ or to control buffer $(\circ)$ at 10, 20, and $30 \mathrm{sec}$. (E) Concentration dependence of the AVP-induced IP3 formation in Cos 1 pMAM-V6 cells measured at 10 sec. (F) Pharmacologic properties of the V6 CDNA encoded AVP receptor. Competition for ${ }^{3} \mathrm{H}$-AVP specific binding on intact Cos lpMAMV6 cells by various AVP analogs is presented in comparison to dissociation by unlabeled AVP per se $(\bullet)$. ( $\bullet)$, V 1 antagonist, $\left.\left[\mathrm{dCH}_{2}\right)_{5}, \operatorname{Tyr}(\mathrm{Me})\right]-A V P(24) ;(\diamond) \mathrm{Vl} / \mathrm{V} 2$ antagonist, $\left[\mathrm{d}\left(\mathrm{CH}_{2}\right)_{5}\right.$, D-Ile $\left.{ }^{2}, \mathrm{Ile}^{4}\right]$-AVP (25); and (०), V2 agonist, DVDAVP (26). Values for respective affinities $\left(K_{d}\right.$ and $\left.K_{i}\right)$ are presented in Table 1. Results shown in (A), (B), (C), (D), and (E) are from experiments performed in triplicate with corresponding standard deviations (bars). Results shown in (F) are from experiments performed in triplicate with an average standard deviation of $8.7 \%$. cells. Comparing the percent activity of respective hormone-induced ${ }^{45} \mathrm{Ca}^{2+}$ efflux, the specificity of the response to AVP by CosIpMAM-V6 cells was evident. As shown in Figure 3B, $1 \mathrm{nM}$ of angiotensin II (AngII), bradykinin, and endothelin-1 did not elicit any ${ }^{45} \mathrm{Ca}^{2+}$ efflux. Furthermore, a highly specific Vl antagonist, $\left[\mathrm{d}\left(\mathrm{CH}_{2}\right)_{5}, \operatorname{Tyr}(\mathrm{Me})\right]$-AVP (24), completely blocked AVP-induced ${ }^{45} \mathrm{Ca}^{2+}$ efflux. To confirm the specificity of AVP-induced $\mathrm{Ca}^{2+}$ mobilization, we analyzed the dose-response curve of CoslpMAM-V6 cells to AVP (Fig. 3C). Analyzing the percent activity of ${ }^{45} \mathrm{Ca}^{2+}$ efflux induced at varying concentrations of AVP $\left(10^{-13}\right.$ to $\left.10^{-7} \mathrm{M}\right)$, a dose-response curve with an $E C_{50}$ of $50 \mathrm{pM}$ was exhibited by Cos IpMAM-V6 cells.

To study the coupling of the V6 encoded receptor to early cellular biochemical events responsible for the calcium flux, we investigated the AVPinduced phospholipase C-mediated phosphoinositide hydrolysis in CoslpMAM-V6 cells. As shown in Figure 3D, $0.1 \mu \mathrm{M}$ of AVP induced IP3 formation in CoslpMAM-V6 cells peaking at $10 \mathrm{sec}$. The time course is consistent with the AVP-induced phosphoinositide hydrolysis being an early event responsible for the AVP-induced $\mathrm{Ca}^{2+}$ mobilization. Moreover, when we analyzed the IP3 formation induced at varying concentrations of AVP $\left(10^{-12}-10^{-7} \mathrm{M}\right)$, a dose response curve with an $E C_{50}$ of $50 \mathrm{pM}$ was exhibited by CoslpMAM-V6 cells (Fig. 3E). This value is consistent with the $\mathrm{Ca}^{2+}$ efflux measurements (Fig. 3C) and further confirms the specificity of the AVP response.

The functional coupling of an AVP responsive receptor to a $\mathrm{Ca}^{2+}$ mobilizing transduction system via phospholipase $\mathrm{C}$-mediated phosphoinositide hydrolysis suggests a V1-type AVP receptor $(5,6)$. To further investigate this, we analyzed the agonist/ antagonist pharmacologic response profile of V6encoded receptors on intact Cos 1pMAM-V6 cells. As seen in Figure 3F and Table 1, the pharmacologic profile of the V6-encoded receptor analyzed by displacement of ${ }^{3} \mathrm{H}$-AVP reveals specificity for AVP with a calculated affinity constant of $6 \mathrm{nM}$. A highly specific Vl-antagonist, $\left[\mathrm{d}\left(\mathrm{CH}_{2}\right)_{5}, \operatorname{Tyr}(\mathrm{Me})\right]$-AVP (24), displaced AVP exhibiting an inhibition constant $\left(K_{i}\right)$ of $250 \mathrm{nM}$. A dual V1/V2 type AVP antagonist, $\left[\mathrm{d}\left(\mathrm{CH}_{2}\right)_{5}, \mathrm{D}-\mathrm{Ile}^{2}, \mathrm{Ile}^{4}\right]$-AVP (25) and a highly potent V2-type agonist, DVDAVP [1-deamino, $\mathrm{Val}^{4}$, D-Arg ${ }^{8}$ ]-AVP (26) elicited less displacement efficiency with equal $K_{i}$ values of $600 \mathrm{nM}$.

\section{Topography of the V6 cDNA Encoded Vasopressin Receptor}

To ascertain the predicted topography of the V6 cDNA encoded AVP receptor, we performed immunocytochemical studies on intact (nonpermeabilized) Cos IpMAM-V6 transfectants utilizing a polyclonal antipeptide antibody raised against amino acids 11-20 of the predicted extracellular domain (Fig. 2). As shown in Figure 4, prominent staining was observed in pMAM-V6 transfectants 
Table 1. Kinetic parameters of V6 cDNA encoded vasopressin V1-type receptor.

\begin{tabular}{|c|c|c|c|}
\hline & $E C_{50}(\mathrm{nM})$ & $K_{i}(\mathbf{n} \mathbf{M})$ & $B_{\max }\left(\right.$ fmols $10^{-6}$ cells) \\
\hline${ }^{45} \mathrm{Ca}^{2+}$ efflux & $0.050 \pm 0.007$ & & \\
\hline IP3 formation & $0.050 \pm 0.006$ & & \\
\hline AVP & & $6.0 \pm 0.9$ & $8.4 \pm 0.7$ \\
\hline Vl antagonist ${ }^{a}$ & & $250.0 \pm 18.0$ & \\
\hline V1/V2 antagonist ${ }^{b}$ & & $600.0 \pm 34.0$ & \\
\hline V2 agonist (DVDAVP) ${ }^{c}$ & & $600.0 \pm 43.0$ & \\
\hline
\end{tabular}

${ }^{a}\left[\mathrm{~d}\left(\mathrm{CH}_{2}\right)_{5}, \operatorname{Tyr}(\mathrm{Me})\right]-\mathrm{AVP}$.

${ }^{b}\left[\mathrm{~d}\left(\mathrm{CH}_{2}\right)_{5}, \mathrm{D}-\mathrm{Ile}^{2}, \mathrm{Ile}^{4}\right]-\mathrm{AVP}$.

${ }^{c}$ DVDAVP[1-deamino, Val $\left.^{4}, \mathrm{D}-\mathrm{Arg}^{8}\right]$-AVP.

Affinity constants ( \pm error) were determined by Scatchard analysis (KELL for Windows, BIOSOFT) of data presented in Figure 3.

(Fig. 4B) in contrast to no staining in control CoslpMAMneo transfectants (Fig. 4A), thus corroborating the predicted topography and cell membrane localization of the V6 vasopressin type-1 receptor.

\section{Discussion}

Several characteristics of the V6 cDNA encoded AVP receptor strongly suggest that it is of the V1-type. The V6 mRNA tissue distribution is consistent with the tissue distribution of $\mathrm{V} 1$ receptors detected pharmacologically $(1,5,6)$. Its predominance in vascular tissue and smooth muscle cells is also consistent with the tissue distribution of vasopressor V1-type AVP receptors $(1,5,6)$. Moreover, the specificity for AVP as ligand $\left(K_{d}=6 \mathrm{nM}\right)$, the functional coupling to a transduction system that mobilizes $\mathrm{Ca}^{2+}\left(E C_{50}=50 \mathrm{pM}\right)$, and the greater affinity for a Vl antagonist $\left(K_{i}=250 \mathrm{nM}\right)$ over a dual V1/V2 antagonist and a potent V2 agonist, DVDAVP, ( $K_{i}=600 \mathrm{nM}$ for both) are strong evidence supporting the notion that the V6 cDNA encodes an AVP receptor of the $\mathrm{V} l$ type. In contrast, the previously characterized AngII/AVP V2-type receptor exhibits a $K_{i}$ of $109 \mathrm{nM}$ for DVDAVP, and a $K_{i}$ above 13,000 nM for the same Vl antagonist (27). The large disparity between $\left[{ }^{3} \mathrm{H}\right]$-AVP dissociation constant (6 nM) and the $E C_{50}$ s for stimulated IP3 formation and ${ }^{45} \mathrm{Ca}-\mathrm{eflux}$ $(0.05 \mathrm{nM})$ suggest that only a small proportion $(\sim 1 \%)$ of the expressed receptor is functionally coupled to the signal transduction system (presumable a $G$ protein). Due to the low specific activity of $\left[{ }^{3} \mathrm{H}\right]$-AVP and the low number of receptors expressed in Cos 1 pMAM-V6 cells (8.4 fmols $10^{-6}$ cells; Table 1$)$, we were unable

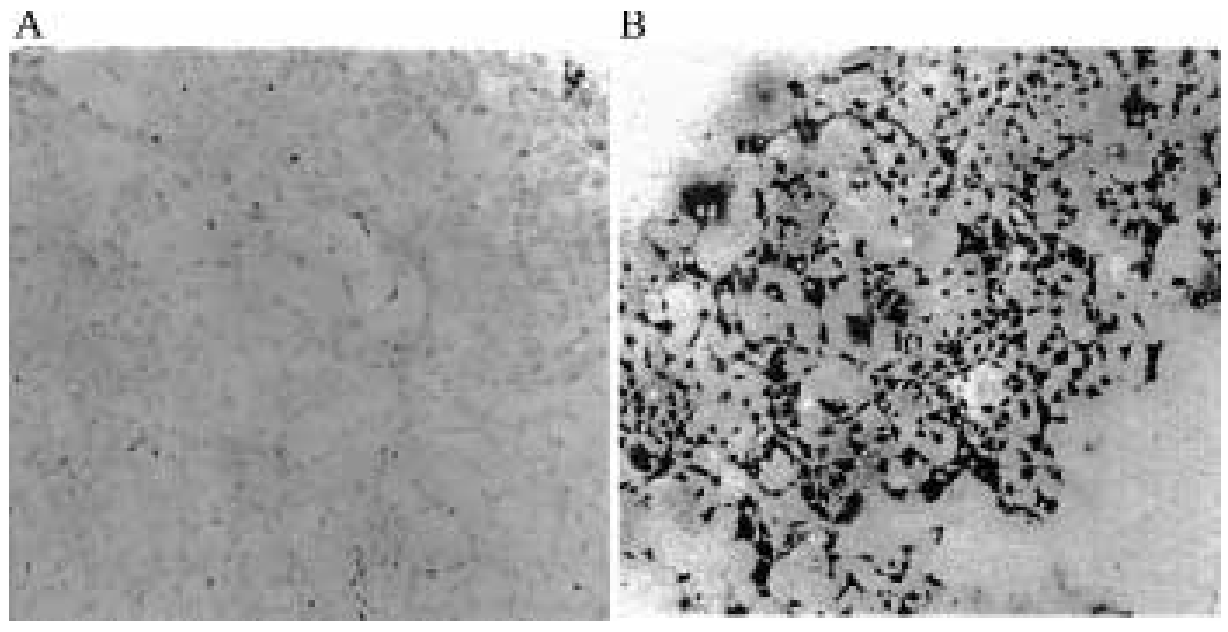

Fig. 4. Immunocytochemical localization of the V6 cDNA encoded V1-type AVP receptor in CoslpMAM-V6 stable transfectants demonstrating predicted topography. (A) Control CoslpMAMneo transfectants show minimal background staining. (B) CosIpMAM-V6 transfectants show intense immunoreactivity with the polyclonal antipeptide antibody raised against the predicted extracellular peptide $\mathrm{L}_{11}$ WLPEDGQVR 20 (see Fig. 2). Primary antibody was reacted with intact cells followed by immunostaining as described in Materials and Methods. 
to detect the receptor high-affinity AVP binding site that most likely accounts for activation of signal transduction.

The predicted AVP binding domain of the V6 encoded receptor differs considerably in primary amino acid sequence from the predicted AVP binding domain of the recently described AngII/ AVP receptor (11). This would indicate that different amino acid sequences could fulfill the structural requirements for AVP binding as was previously observed for AngII binding by the AngII/AVP receptor (11) and ET-1/AngII receptor (12) AngII binding domains. We note that the precise amino acid(s) that contact AVP within this predicted AVP binding domain remain to be determined through specific sitedirected mutagenesis and/or crystallographic studies.

Analysis of nucleotide and deduced amino acid sequence homology with other cloned vasopressin receptors (7-10) and with other representative members of the seven transmembrane domains G protein-coupled receptor superfamily $(28,29)$ revealed no sequence identity. A similar topography (a single transmembrane domain) was also observed in the recently reported ET-1/AngII receptor (12) that was identified on the basis of the MRT as well. These observations are consistent with the MRT as the basis of the evolutionary origin of AVP, AngII, and ET- 1 receptors. It is conceivable that in the evolution of these receptors, exon shuffling of the antipeptide oligonucleotides occurred into different membrane-spanning proteins, thus accounting for the quite different polypeptide sequences but conserved antipeptide-derived putative binding domain regions observed in today's receptors. Nevertheless, the isolation of two types of AVP receptors in the single cDNA screening done with the AVP antipeptidebased oligonucleotide probe, the AngII/AVP receptor (11) and the V6 cDNA-encoded vasopressin VI-type receptor reported here, supports the molecular recognition theory as the basis of the evolution of the AVP ligand-receptor system. Numerous studies have reported experimental evidence in support of this theory (see references 11,30 and citations therein). However, the MRT remains controversial; some biochemical and theoretical analyses testing the potential validity of the MRT have reported negative results (31-37). Nevertheless, our studies underscore the importance of investigating other peptide-hormone receptor systems for a full understanding of their evolution and function, as well as to gain further insights into the general applicability of the molecular recognition theory to the evolution of the presently known biological systems.

\section{Acknowledgments}

We thank G.N. Prado for technical assistance. This study was supported by a grant from the National Institutes of Health, HL 60071.

\section{References}

1. Gash DM, Boer GJ. (1987) Vasopressin: Principles and Properties. New York: Plenum.

2. Szczepanska-Sadowska E. (1996) Interaction of vasopressin and angiotensin II in central control of blood pressure and thirst. Regul. Pept. 66: 65-71.

3. Toba K, Ohta M, Kimura T, Nagano K, Ito S, Ouchi Y. (1998) Role of brain vasopressin in regulation of blood pressure. Prog. Brain. Res. 119: 337-349.

4. Jordan J, Tank J, Diedrich A, Robertson D, Shannon JR. (2000) Vasopressin and blood pressure in humans. Hypertension 36: E3-E4.

5. Jard S. (1983) Vasopressin isoreceptors in mammals: Relation to cyclic AMP-dependent and cyclic AMP-independent transduction mechanisms. Curr. Topics Memb. Transp. 18: 255-283.

6. Jard S. (1987) Vasopressin antagonists. Adv. Nephrol. 16: 1-16.

7. Morel A, O'Carroll A-M, Brownstein MJ, Lolait SJ. (1992) Molecular cloning and expression of a rat $\mathrm{V}_{1 \mathrm{a}}$ arginine vasopressin receptor. Nature 356: 523-526.

8. Sugimoto T, Saito M, Mochizuki S, Watanabe Y, Hashimoto S, Kawashima H. (1994) Molecular cloning and functional expression of a cDNA encoding the human Vlb vasopressin receptor. J. Biol. Chem. 269: 27088-27092.

9. Birnbaumer M, Seibol A, Gilbert S, et al. (1992) Molecular cloning of the receptor for human antidiuretic hormone. Nature 357: 333-335.

10. Lolait SJ, O'Carrol AM, McBride OW, Konig M, Morel A, Brownstein MJ. (1992) Cloning and characterization of a vasopressin $V_{2}$ receptor and possible link to nephrogenic diabetes insipidus. Nature 357: 336-339.

11. Ruiz-Opazo N, Akimoto K, Herrera VLM. (1995) Identification of a novel dual angiotensin II/vasopressin receptor on the basis of molecular recognition theory. Nat. Med. 1: 1074-1081.

12. Ruiz-Opazo N, Hirayama K, Akimoto K, Herrera VLM. (1998) Molecular characterization of a dual Endothelin-1/ Angiotensin II receptor. Mol. Med. 4: 96-108.

13. Blalock JE. (1995) Genetic origins of protein shape and interaction rules. Nat. Med. 1: 876-878.

14. Ivell R, Richter D. (1984) Structure and comparison of the oxytocin and vasopressin genes from rat. Proc. Natl. Acad. Sci. U.S.A. 81: 2006-2010.

15. Herrera VLM, Chobanian AV, Ruiz-Opazo N. (1988) Isoformspecific modulation of $\mathrm{Na}^{+}, \mathrm{K}^{+}$-ATPase $\alpha$-subunit gene expression in hypertension. Science 241: 22 1-223.

16. Herrera VLM, Ruiz-Opazo N. (1990) Regulation of $\alpha$ tropomyosin and N5 genes by a shared enhancer: modular structure and hierarchical organization. J. Biol. Chem. 265: 9555-9562.

17. Rogers TB, Gaa ST, Allen IS. (1986) Identification and characterization of functional angiotensin II receptors on cultured heart myocytes. J. Pharmacol. Exp. Ther. 236: 438-444.

18. Brown RD, Berger KD, Taylor P. (1984) $\alpha$ l-adrenergic receptor activation mobilizes cellular $\mathrm{Ca}^{++}$in a muscle cell line. J. Biol. Chem. 259: 7554-7562.

19. Bost KL, Smith EM, Blalock JE. (1985) Similarity between the corticotrophin (ACTH) receptor and a peptide encoded by an RNA that is complementary to ACTH mRNA. Proc. Natl. Acad. Sci. U.S.A. 82: 1372-1375.

20. Grillone LR, Clark MA, Godfrey RW, Stassen F, Crooke ST. (1988) Vasopressin induces Vl receptors to activate phosphatidylinositol- and phosphatidylcholine-specific phospholipase $C$ and stimulates the release of arachidonic acid by at least two pathways in the smooth muscle cell line, A-10. J. Biol. Chem. 263: 2658-2663.

21. Kozak M. (1984) Compilation and analysis of sequences upstream from the translational start site in eukaryotic mRNAs. Nucl. Acids Res. 12: 857-872.

22. Kyte J, Doolittle RF. (1982) A simple method for displaying the hydropathic character of a protein. J. Mol. Biol. 157: 105-132.

23. Engelman DM, Steitz TA, Goldman A. (1986) Identifying nonpolar transbilayer helices in amino acid sequences of membrane proteins. Annu. Rev. Biophys. Biophys. Chem. 15: 321-353. 
24. Kruszynski M, Lammek B, Manning M. (1980) [1-( $\beta$-mercapto$\beta, \beta$-cyclopentamethylenepropionic acid)],2-(O-methyl)tyrosine]arginine-vasopressin and [1-( $\beta$-Mercapto- $\beta, \beta$-cyclopentamethylenepropionic acid)] arginine-vasopressin, two highly potent antagonists of the vasopressor response to arginine vasopressin. J. Med. Chem. 23: 364-368.

25. Manning M, Nawrocka E, Misicka A, et al. (1984) Potent and selective antagonists of the antidiuretic responses to arginine vasopressin based on modifications of $[1,(\beta$-mercapto- $\beta$, $\beta$-pentamethylenepropionic acid), 2-D-isoleucine, 4-valine], arginine-vasopressin at position 4. J. Med. Chem. 27: 423-429.

26. Manning M, Balaspiri L, Acosta M, Sawyer WH. (1973) Solid phase synthesis of [1-deamino, 4-valine]-8-arginine vasopressin (DVDAVP), a highly potent and specific antidiuretic agent possessing protracted effects. J. Med. Chem. 16: 975-978.

27. Gonzales CB, Herrera VLM, Ruiz-Opazo N. (1977) Renal immunocytochemical distribution and pharmacological properties of the dual angiotensin II/AVP receptor. Hypertension 29: 957-961.

28. Dohlman HG, Caron MG, Lefkowitz RJ. (1987) A family of receptors coupled to guanine nucleotide regulatory proteins. Biochemistry 26: 2657-2664.

29. Iismaa TP, Shine J. (1992) G protein-coupled receptors. Curr. Opin. Cell Biol. 4: 195-202.

30. Baranyi L, Campbell W, Ohshima K, Fujimoto S, Boros M, Okada H. (1995) The antisense homology box: A new motif within proteins that encodes biologically active peptides. Nat. Med. 1: 894-901.

31. Rasmussen UB, Hesch RD. (1987) On antisense peptides: the parathyroid hormone as an experimental example and a critical theoretical view. Biochem. Biophys. Res. Commun. 149: 930-938.

32. de Gasparo M, Whitebread S, Einsle K, Heusser C. (1989) Are the antibodies to a peptide complementary to angiotensin II useful to isolate the angiotensin II receptor? Biochem. J. 261: 310-311.

33. Golstein A, Brutlag DL. (1989) Is there a relationship between DNA sequences encoding peptide ligands and their receptors? Proc. Natl. Acad. Sci. U.S.A. 86: 42-45.

34. Kelly JM, Trinder D, Phillips PA, et al. (1990) Vasopressin antisense peptide interactions with the VI receptor. Peptides 11: 857-862.

35. Jurzak M, Pavo I, Fahrenholz F. (1993) Lack of interaction of vasopressin with its antisense peptides: a functional and immunological study. J. Recept. Res. 13: 881-902.

36. Eberle AN, Huber M. (1991) Antisense peptides: tools for receptor isolation? Lack of antisense MSH and ACTH to interact with their sense peptides and to induce receptor-specific antibodies. J. Recept. Res. 11: 13-43.

37. Houen G. (1999) Evolution of the genetic code: the nonsense, antisense, and antinonsense codes make no sense. Biosystems 54: $39-46$. 